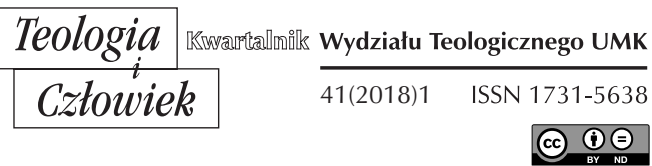

PIOTR RAFAŁ KLAWCZYŃSKI*

TORUŃ

\title{
W POSZUKIWANIU GENEZY, ROZWOJU ORAZ SENSU CHRZEŚCIJAŃSKIEGO KULTU ŚWIĘTYCH I ICH RELIKWII. STUDIUM HISTORYCZNO-TEOLOGICZNE
}

DOI: http://dx.doi.org/10.12775/TiCz.2018.006

\section{WPROWADZENIE}

Kult relikwii, a więc szacunek i w pewnym sensie cześć oddawana szczątkom świętych lub rzeczom, które były związane z tymi osobami, istniał już w czasach starożytnych. Adorowano i strzeżono groby, w których znajdowały się szczątki herosów, czyli półbogów lub bohaterów, ponieważ ludzie żyjący w świecie antycznym wierzyli, że posiadanie mogiły jakiegoś herosa zapewni ich wspólnocie dostatek, pomyślność czy też błogosławieństwo. $\mathrm{W}$ wielu miejscach przechowywano także różne przedmioty, które rzekomo należały do tych starożytnych postaci. Warto w tym miejscu wspomnieć przynajmniej o obuwiu Perseusza i lirze Or-

* Piotr Rafał Klawczyński - absolwent bydgoskich szkół salezjańskich, GTS oraz LOTS; w latach 2009-2014 jednolite studia magisterskie na Wydziale Teologicznym UAM w Poznaniu, sekcja zamiejscowa w Bydgoszczy (piotr_klawczynski@op.pl). 
feusza, których czczono jako półbogów, a także o berle króla trojańskiego Priama i cytrze królewicza trojańskiego Parysa ${ }^{1}$.

Omawiając problematykę związaną z kultem świętych i ich relikwii, należy pamiętać, że tego rodzaju praktyka chrześcijańska nie ma nic wspólnego z wyżej wymienionymi praktykami pogańskimi. Aczkolwiek całkiem niedawno można było usłyszeć o odmiennym stanowisku pewnych teologów żyjących na przełomie XIX i XX wieku. Otóż ci właśnie „przedstawiciele szkoły religijno-historycznej sugerowali, iż niektórzy święci chrześcijańscy są po prostu kontynuatorami pogańskich bóstw, a sam kult świętych jest dalszym ciągiem politeizmu"2. Przeciwko tezom głoszonym przez tych teologów „przemawia fakt, iż cześć świętych zgodnie ze swym źródłem i istotą posiada wybitnie chrześcijański charakter i całkowicie różni się od prymitywnych wyobrażeń i praktyk pogańskich”3. Ponadto zmarli, którzy dostąpili zbawienia, nie stają się bogami. Nawet ci, którzy zostali beatyfikowani lub kanonizowani. Mogą wstawiać się za nami u Boga, ale ich uprzywilejowana pozycja nie wprowadza elementu politeistycznego. Religia chrześcijańska ma charakter monoteistyczny.

\section{KULT ŚWIĘTYCH I ICH RELIKWII W BIBLII}

W Starym Testamencie nie odnajdziemy typowego kultu relikwii ludzi uznanych za świętych, który jest charakterystyczny dla okresu poapostolskiego i późniejszych wieków. W czasach przed Chrystusem każda osoba, która dotknęła ludzkich zwłok, przebywała w ich otoczeniu lub znalazła się w miejscu zgonu jakiegoś człowieka, była uważana za nieczystą i wymagała oczyszczenia ${ }^{4}$. Tak rygorystyczna postawa wynikała

1 Autor w swoim artykule wspomina dodatkowo o zasłonie słynnej Heleny, znajdującej się niegdyś w ateńskiej świątyni wraz ze wspomnianym berłem Priama, a także o włóczniach Marsa, który z kolei był czczony przez rzymski starożytny świat. Por. M. Budziarek, Kult relikwii w starożytnym chrześcijaństwie, „Ruch Biblijny i Liturgiczny” 5 (1979), s. 276.

2 Tamże.

3 Tamże.

${ }^{4}$ Por. J. Charkiewicz, Relikwie świętych $w$ prawosławiu, Warszawa 2010, s. 15. Należy zwrócić uwagę, że autor tej pozycji, w tym samym miejscu, popełnił błąd, twierdząc, że tego typu zachowanie wobec zmarłych nie wynikało ze wskazań prawnych 
z biblijnych nakazów czy też zakazów, które możemy odnaleźć w Księdze Liczb (zob. Lb 19,11-16 oraz Lb 19,17-22). W dzisiejszych czasach zakaz dotykania ciał osób zmarłych może być czymś niezrozumiałym. Jednak w rozumieniu starotestamentowym śmierć była karą za popełniony przez człowieka grzech. W dodatku ten zakaz prawny mógł być próbą, metodą lub inaczej mówiąc dobrym sposobem, aby przeciwstawić się i zapobiec kultowi zmarłych, który charakteryzował wtedy świat pogański ${ }^{5}$, co zostało wyraźnie zasygnalizowane we wstępie tego artykułu.

Niemniej jednak, studiując wnikliwie treść zapisaną na kartach Starego Testamentu, możemy natrafić na kilka przykładów szacunku wobec szczątków ludzkich tych osób, które za życia były wierne i oddane Bogu, a także odnajdziemy ciekawe historie związane $\mathrm{z}$ ich grobami, pomimo surowego prawa izraelskiego dotyczącego rozumienia śmierci i traktowania miejsc zgonów, pochówków oraz obchodzenia się z ciałami zmarłych. Józef prosił, aby po jego odejściu z tego świata synowie Izraela zabrali z Egiptu jego kości, które ostatecznie złożono na polu w Sychem ${ }^{6}$, wypełniając w ten sposób ostatnią wolę Józefa: „A kości Józefa, które synowie Izraela zabrali ze sobą z Egiptu, pochowano w Sychem, na części pola, kupionego przez Jakuba od synów Chamora, ojca Sychema, za sumę stu kesitów" (Joz 24, 32). Jozjasz, który był królem judejskim, z wielkim zaangażowaniem zburzył miejsca kultu bałwochwalczego, zniszczył tamtejsze grobowce, a kości w nich złożone spalił na pogańskim ołtarzu.

znajdujących się w Biblii. Otóż przepisy prawne dla Izraelitów regulowały tę kwestię w Księdze Liczb. Warto również wskazać na pewną nieścisłość popełnioną przez tego autora, również na stronie piętnastej. Jarosław Charkiewicz stwierdził bowiem, że istnieje coś takiego jak kult szczątków osób uznanych za świętych w rozumieniu właściwym Nowemu Testamentowi. Należy uściślić także tę wypowiedź i dodać, że okres nowotestamentowy, tak jak Stary Testament, również nie znał praktyk związanych z kultem relikwii, który jest charakterystyczny dopiero dla czasów poapostolskich i późniejszych wieków, co zostało już zaznaczone w tym artykule. Aczkolwiek ta praktyka chrześcijańska jest związana z nauczaniem o świętym obcowaniu i być może przywołany autor to właśnie miał na myśli, pisząc o rozumieniu nowotestamentowym, czyli o pewnym novum zrodzonym w społeczności chrześcijańskiej. Zob. tamże.

${ }^{5}$ Por. Przypadki rytualnej nieczystości, w: Pismo Święte Starego i Nowego Testamentu. Najnowszy przekład z języków oryginalnych z komentarzem, red. T. Brzegowy, Częstochowa 2009, s. 299.

${ }^{6}$ Por. J. Charkiewicz, Relikwie, s. 15-16. 
Jednak kiedy natrafil na grób pewnego proroka, postanowił zachować tę mogiłę i nakazał, aby nie ruszać jego kości ${ }^{7}$, co jest kolejnym przykładem starotestamentalnego szacunku wobec niektórych zmarłych, którzy podczas swego ziemskiego życia wiernie służyli jedynemu Bogu (zob. $2 \mathrm{Krl}$ 23,16-19). Ostatnim wydarzeniem w Starym Testamencie, o którym warto wspomnieć, był pogrzeb pewnego człowieka, którego ciało wrzucono do miejsca, gdzie pochowano wcześniej proroka Elizeusza. Nagle człowiek ten ożył, gdy tylko jego martwe ciało zetknęło się z kośćmi tego proroka. Przywołane trzy starotestamentalne historie stanowią pewne zaczątki przyszłego kultu ciał świętych i rzeczy z nimi związanych ${ }^{8}$, który narodził się po przyjściu Jezusa Chrystusa na świat w grocie betlejemskiej, a precyzyjniej określając zakres czasowy, pojawił się w czasach poapostolskich i trwa do dziś.

Na kartach Nowego Testamentu możemy odnaleźć kilka świadectw wskazujących między innymi na przedmioty posiadające szczególną moc, dzięki której chorzy odzyskiwali zdrowie. Ich właścicielami byli Jezus Chrystus $^{9}$ oraz święty Paweł z Tarsu. Historie dwóch pierwszych cudów, które należy w tym miejscu przytoczyć, dotyczą płaszcza czy też frędzli płaszcza Zbawiciela. To opowieść o kobiecie, która od wielu lat zmagała się z krwotokiem (zob. Mt 9,20-22), a także relacja dotycząca uzdrowień w Genezaret (zob. Mk 6,53-56). Pozostałe cuda, związane z Apostołem Narodów, zostały uwiecznione w Dziejach Apostolskich: „Bóg czynił też niezwykłe cuda przez ręce Pawła, tak że nawet chusty i przepaski z jego ciała kładziono na chorych, a choroby ustępowały z nich" (Dz 19,1112).

7 Por. tamże, s. 16.

${ }^{8}$ Por. tamże, s. 16-17. Natomiast o cudzie, który został wspomniany w tym fragmencie artykułu, można przeczytać w Drugiej Księdze Królewskiej (zob. 2 Krl 13,2021). Moc płynąca przez Elizeusza (lub inaczej mówiąc moc przepływająca przez niego, co jest z pewnością bardziej zrozumiałym i adekwatnym określeniem, gdyż w tym przypadku prorok, jak również w wielu innych miejscach każdy zwykły człowiek, jest i może być narzędziem w ręku Boga, który posługuje się nim, aby uczynić jakieś dobro na ziemi), która sprawia, że zmarły wrócił do życia, oddziałuje na innych nawet po śmierci proroka, ponieważ źródłem tej mocy jest miłość i miłosierdzie Boga, a także Jego wierność wobec obietnicy czy też przysięgi złożonej wcześniej patriarchom. Por. Śmierć Elizeusza, w: Pismo Święte Starego i Nowego Testamentu, s. 700.

9 Por. M. Budziarek, Kult relikwii, s. 276. 
Śmierć diakona Szczepana i jego pogrzeb bywają niejednokrotnie traktowane jako początek kultu relikwii ${ }^{10}$, w tym przypadku męczennika, który oddał swe życie za wiarę w Jezusa Chrystusa (zob. Dz 7,55-8,2). Analizując ten fragment Dziejów Apostolskich, możemy dojść do wniosku, że teza o męczeństwie, śmierci i pochówku diakona Szczepana jako początku chrześcijańskiego kultu relikwii świętych jest błędna i zupełnie bezpodstawna. W słowach o wielkim żalu ludzi pobożnych, którzy pochowali Szczepana, nie jesteśmy w stanie odnaleźć jakiegokolwiek śladu pewnego rodzaju kultu osób lub rzeczy z nimi związanych - czy to ludzi tragicznie zmarłych, czy też osób uznanych za świętych ze względu na ich gorliwą wiarę. Ten żal wierzących, któremu z pewnością towarzyszył płacz i lament, mógł być po prostu reakcją na to, co zobaczyli. Ich wielki dobroczyńca, opiekun ludzi ubogich i potrzebujących, a także wdów i sierot, został zamordowany, a jego ciało było z pewnością bardzo poranione. Zatem żal nie oznacza jeszcze początku kultu. Co więcej, o jego grobie z biegiem czasu zapomniano, a ponowne odkrycie pochówku świętego Szczepana nastąpiło dopiero w 415 roku $^{11}$, a więc kilka wieków później. Również w przypadku Jana Chrzciciela, który także zginął śmiercią męczeńską, teksty biblijne nie wspominają o jakimkolwiek pośmiertnym kulcie jego osoby (zob. Mk 6,2729).

Dotychczasowa analiza wybranych tekstów biblijnych ukazuje nam, że nie tylko w czasach starotestamentowych, ale jeszcze w Nowym Testamencie nie istniała praktyka ludzi wierzących w jedynego Boga, która polegałaby na typowym kulcie zmarłych, ich doczesnych ciał albo szczątków i rzeczy związanych z tymi osobami. Tego typu chrześcijańska forma pobożności została zapoczątkowana w czasach poapostolskich.

\section{OD CZASÓW POAPOSTOLSKICH DO CZASÓW WSPÓłCZESNYCH}

W środowisku chrześcijańskim relikwie świętych były i wciąż są otaczane ogromną troską i szacunkiem. Postawa ta narodziła się nad

${ }^{10}$ Por. K. Feliś, Pierwsze ślady kultu Relikwii, „Ateneum Kapłańskie” 1 (1909) 5, s. 420.

11 Por. tamże, s. 420-421. Por. M. Budziarek, Kult relikwii, s. 277. 
grobami pierwszych męczenników zabitych z powodu wiary w Jezusa Chrystusa. Postrzegano ich jako tych, którzy przez swoją śmierć stali się Jemu bliżsi, upodobnili się do Niego i bez jakiejkolwiek zwłoki osiągnęli zbawienie wieczne. Wierzono bowiem, że męczennicy mogą od razu wejść do Królestwa Bożego ${ }^{12}$. Przekonanie o możliwości szybkiego dostania się do nieba z pewnością podnosiło na duchu właśnie tych, którzy mieli umrzeć za wiarę, czekających na wyrok lub doznających strasznych katuszy ${ }^{13}$ przy jego wykonywaniu.

Od II wieku we wschodnim chrześcijaństwie, a wiek później na zachodnich terenach chrześcijańskich rozpoczął się wyraźny kult szczątków męczenników, których ciała wierzący w Chrystusa zabierali za pozwoleniem ówczesnej władzy cywilnej lub nawet potajemnie, aby je pochować w przestronnym miejscu, gdzie każdego roku wierni mogliby gromadzić się razem $\mathrm{w}$ rocznicę śmierci tej osoby. Wszystkie wspólnoty złożone z chrześcijan prowadziły pewnego rodzaju kalendarz, który ułatwiał wierzącym orientację, gdzie i kiedy organizowane jest coroczne nabożeństwo związane z rocznicą śmierci konkretnego męczennika. Spis ten zawierał jego imię, dzień śmierci oraz informację dotyczącą lokalizacji cmentarza, jeśli w danej miejscowości znajdowała się większa ich liczba. Podczas tego typu uroczystości, oprócz odmawiania modlitw i czytania tekstów biblijnych, sprawowano Eucharystię, która była najważniejszym i nieodzownym elementem tych obchodów. Dlatego przy ich grobach lub nad nimi stawiano ołtarze. Tego typu zwyczaj motywowano wizją świętego Jana Apostoła, którą możemy odnaleźć w szóstym rozdziale Księgi Apokalipsy ${ }^{14}$ jego autorstwa: „A gdy otworzył pieczęć piątą, ujrzałem pod ołtarzem dusze zabitych dla Słowa Bożego i dla świadectwa, jakie mieli” (Ap 6,9). Należy również wspomnieć, że prawo rzymskie zezwalało na pochówki ciał skazańców, które były wydawane proszącym o nie rodzinom lub innym osobom. Dlatego zdarzało się bardzo często, że nawet w okresie największych represji skierowanych $\mathrm{w}$ stronę chrześcijan organizowano uroczyste pogrzeby wyznawców Jezusa Chrystusa, którzy zginęli za wiarę.

12 Por. T. Sinka, Kult relikwii Świętych $w$ aspekcie historyczno-liturgicznym, „Ruch Biblijny i Liturgiczny" 3 (2003), s. 193.

13 Por. K. Feliś, Pierwsze ślady, s. 434.

14 Por. T. Sinka, Kult relikwii, s. 193-195. 
Zdarzały się jednak odmowy wydania zwłok z różnych powodów ważnych dla rzymskich urzędników. Niejednokrotnie dochodziło wtedy do skazywania na śmierć także tych chrześcijan, którzy niestrudzenie upominali się o zwłoki męczenników ${ }^{15}$, o ciała ich braci w wierze.

Początkowo omawiana forma pobożności chrześcijańskiej ograniczała się w każdym przypadku do lokalnej społeczności, której w zupełności wystarczała przestrzeń w grobowcach lub kryptach, gdy przychodziła oddać cześć relikwiom osób uznanych za świętych. Jednak z biegiem czasu do niektórych z tych miejsc zaczęło przybywać coraz więcej wyznawców Chrystusa, którzy pochodzili z innych miejscowości. Tak narodziły się pielgrzymki do grobów osób świętych, które spowodowały, że zaczęło brakować miejsca dla wszystkich chcących z należytym szacunkiem zobaczyć relikwie, pomodlić się przy nich i adorować je. Z tego właśnie powodu postanowiono budować kościoły, które mogły pomieścić większą ilość wiernych. Świątynie musiały być zaprojektowane w ten sposób, aby znajdujące się w nich ołtarze były zlokalizowane nad miejscami pochówków męczenników ${ }^{16}$.

Choć na wschodnich obszarach chrześcijańskich nie przestrzegano aż tak zasady nietykalności grobów osób zmarłych, ponieważ już pod koniec III i na początku IV wieku dzielono na tych obszarach relikwie, a nawet w IV stuleciu dokonywano ich przenosin, to w zachodnim świecie chrześcijańskim tylko poza Rzymem można było ewentualnie spotkać się z tego typu praktykami. Rzym dość długo przestrzegał prawa dotyczącego nietykalności grobów ludzkich, czyli w rezultacie zakazywał dzielenia ciał czy też szczątków świętych i przenoszenia ich w inne miejsce. Jednak po pewnym czasie również on musiał zacząć praktykować zwyczaj przenoszenia relikwii, aby uchronić je przed napływającymi plemionami barbarzyńskimi ${ }^{17}$.

15 Por. K. Feliś, Pierwsze ślady, s. 420.

16 Por. T. Sinka, Kult relikwii, s. 195.

17 Por. tamże, s. 195-196. W czasach przestrzegania zasady o nietykalności zwłok ludzkich, a więc na zachodnich obszarach chrześcijańskich, nie można było jednak zlekceważyć ogromnego popytu na relikwie świętych. Dlatego zaczęto stosować kawałki drogocennych materiałów, które przez zetknięcie się „z grobem Chrystusa lub męczennika, świętym miejscem lub relikwią same stawały się relikwiami. Bardziej lub mniej długotrwały kontakt powodował przekazanie mocy zawartej w relikwii. Zwyczaj 
W zachodnim świecie chrześcijańskim dopiero od końca VI i początku VII wieku przenoszenie całych ciał świętych lub ich dzielenie i przenoszenie $\mathrm{w}$ częściach stało się praktyką powszechną i popularną. Nastąpił dzięki temu wzrost tego rodzaju pobożności chrześcijańskiej związanej z kultem relikwii, a same kościoły nie musiały już być budowane na grobach świętych. Pod stołami ofiarnymi składano ich relikwie, co stało się w VII wieku zasadą obowiązującą ${ }^{18}$. Przenoszenie relikwii zawsze miało „charakter uroczysty, co pogłębiało i umacniało ten kult. Przeniesienie relikwii co roku wspominano w liturgii, na równi z obchodami rocznicy"19 śmierci danego świętego. Ponadto w średniowieczu podnoszono relikwie świętych i ukazywano je wiernym. Relikwie umieszczano na honorowym miejscu, aby wszyscy mogli je zobaczyć. Niestety pojawiło się także zjawisko fałszowania relikwii, a w czasach oświecenia kult ten uległ znacznemu osłabieniu. Jednak w liturgii relikwie były wciąż otaczane wielką czcią ${ }^{20}$,

ten miał zapewne swe źródła w głębokiej wierze w cudowne uzdrawiające dotykanie szat Chrystusa, opisane w Ewangelii św. Marka”. K. Szczepkowska-Naliwajek, Relikwiarze średniowiecznej Europy od IV do poczatku XVI wieku. Geneza, treść, styl i techniki wykonania, Warszawa 1996, s. 29. Z omówionymi w tym miejscu materiałami wiąże się również dość ciekawa historia. Pewnego razu „do Rzymu przybyła delegacja z prośbą do papieża Grzegorza Wielkiego o kilka relikwii dla kościoła. Papież kazał przygotować białe płótno, którym dotknięto ciał świętych, po czym nakazał je umieścić w zapieczętowanej skrzynce. $\mathrm{W}$ drodze powrotnej z ciekawości otwarto skrzynkę, aby zobaczyć co zawiera. Kiedy delegaci zapoznali się z zawartością, powrócili do Rzymu skarżąc się Ojcu Świętemu, że nie dał im prawdziwych relikwii. Wówczas papież położył na ołtarzu tkaninę i po odmówieniu modlitwy przebił ją nożem, a wówczas wypłynęła krew”. F. Bouchard, Wielkie cuda pobożności czyli skarby Kościoła wsparciem dla Ludu Bożego, tłum. C. Bogdali, Gdańsk 2002, s. 34.

${ }^{18}$ Por. T. Sinka, Kult relikwii, s. 196. Kodeks Prawa Kanonicznego z 1983 roku również przewiduje praktykę związaną ze składaniem relikwii męczenników czy też innych świętych pod ołtarzem: „Starożytna tradycja umieszczania relikwii [...] pod ołtarzem stałym winna być zachowana, zgodnie $\mathrm{z}$ normami podanymi w księgach liturgicznych". Kodeks Prawa Kanonicznego, kan. 1237, $\$ 2$. Bowiem ,szkatuły z relikwiami nie należy umieszczać nad ołtarzem ani w mensie ołtarza, ale pod mensą ołtarzową). Komentarz do Kodeksu Prawa Kanonicznego. Tom III/2. Księga IV. Uświęcające zadanie Kościoła. Część I. Sakramenty. Część II. Pozostałe akty kultu Bożego. Czesść III. Miejsca i czasy święte, red. W. Góralski, E. Górecki, J. Krukowski, J. Krzywda, P. Majer, B. Zubert, Poznań 2011, s. 456.

19 T. Sinka, Kult relikwii, s. 196.

${ }^{20}$ Przy zagadnieniu ukazywania wiernym relikwii należy także wspomnieć, że „smak artystyczny każdego okresu kształtował różne formy relikwiarzy sprzyjających 
co z pewnością sprawiło, że kult świętych, a tym samym cześć i szacunek wobec ich zachowanych ciał czy też kości oraz rzeczy z nimi związanych przetrwał do czasów współczesnych.

\section{NAUKA KOŚCIOŁA PRAWOSŁAWNEGO ORAZ WIZJA PROTESTANCKA}

Prawosławne rozumienie sacrum wyraża się między innymi w podejściu wierzących do relikwii osób świętych, które traktowane są jako miejsca ich szczególnej obecności dzięki łasce. Uważają, że umarłe ciało każdego świętego pozostaje nadal powiązane $\mathrm{z}$ duchem tego człowieka. To znaczy, że pomiędzy cielesnością i tym, co duchowe trwa nadal silna więź. Natomiast niezniszczalność ciała, nawet jego małego fragmentu, jest początkiem przyszłej chwały. W tym właśnie dostrzegają moc relikwii, w których święci niejako przebywają wciąż na ziemi ${ }^{21}$. Nie bez powodu w Kościele prawosławnym jednym z kilku warunków, aby zaliczyć kogoś w poczet świętych, jest czasami zachowane lub inaczej mówiąc nierozłożone ciało potencjalnego kandydata do wyniesienia na ołtarze ${ }^{22}$. Należy pamiętać, że prawosławni czczą nie tylko relikwie, ale również ikony, w których także dopatrują się obecności świętych wśród nas ${ }^{23}$. Jak już zostało wspomniane, według nauki Kościoła prawosławnego „kult relikwii, jak i ikon opiera się na ścisłym związku ducha z ciałem, który to związek nie ulega przerwaniu w momencie śmierci [...]. Oddając cześć świętym relikwiom, czcimy świętego, do którego one należą, wychwalając przy tym Boga, że uświęcone przez Niego ciało świętego nie zanikło po śmierci. Podobnie rzecz ma się z ikonami świętych i kultem tych ikon. Czcząc bowiem ikony świętych, oddajemy cześć nie desce, na której święty został

rozwojowi ich kultu, od konfesji do krypty, od wysokiego grobu za ołtarzem i szklanych sarkofagów barokowych do małych relikwiarzy”. Por. tamże, s. 196-198.

${ }^{21}$ Por. J. Charkiewicz, Relikwie, s. 3, 67.

${ }^{22}$ Por. J. Marecki, L. Rotter, Jak czytać wizerunki świętych. Leksykon atrybutów i symboli hagiograficznych, Kraków 2013, s. XI.

23 Por. J. Charkiewicz, Relikwie, s. 67. 
przedstawiony, oraz farbom, za pomocą których powstało jego oblicze, lecz czcimy osobę, która została na ikonie przedstawiona"24.

Nauka prawosławna wskazuje również na możliwość doświadczenia cudów w obecności relikwii i ikon świętych, a także poczucia wydobywającej się z nich aromatycznej mirry. Natomiast w przeciwieństwie do wiary Kościoła katolickiego oraz Kościoła prawosławnego, nauka protestancka nie wspomina o kulcie świętych, a w ich świątyniach nie odnajdziemy relikwii świętych. Protestanci niestety odrzucają istnienie świętych w naszym katolickim rozumieniu oraz jakiekolwiek przejawy kultu z tym związane. Wśród wielu zarzutów odrzucają na przykład kwestię związaną z nierozkładalnością relikwii ${ }^{25}$, a więc ciał świętych, co $\mathrm{z}$ kolei jest elementem raczej pożądanym wśród prawosławnych.

\section{ZAKOŃCZENIE}

Podróżując po świecie starotestamentalnym, mogliśmy natrafić na postawę szacunku wobec ciała osoby zmarłej, kiedy czytaliśmy opowieść o pewnym proroku, którego grób król Jozjasz zakazał niszczyć, a jego kości nie zostały spalone. Spotkaliśmy się także z przejawem odpowiedniej troski o ludzkie szczątki, tak jak to było w przypadku Józefa, którego zwłoki zostały zabrane z Egiptu przez synów Izraela, zgodnie z jego prośbą. Aczkolwiek prawo żydowskie było bardzo rygorystyczne w stosunku do ciał osób zmarłych i przez to nie spotkaliśmy tam wielu tak pozytywnych przykładów szacunku wobec ludzkich zwłok, nie mówiąc już o ich kulcie. Być może dlatego, że wyznawcy jedynego Boga musieli walczyć z pogańską formą kultu zmarłych, gdzie można było zetknąć się z groźnym politeizmem, czyli wielobóstwem. Tym samym doszliśmy do czasów chrześcijańskich, w których natrafiliśmy na zupełnie inne spo-

24 Tamże, s. 67, 69.

25 Oto fragment Pisma Świętego, na który, według Jarosława Charkiewicza, powołują się protestanci: „Zapewniam was, bracia, że ciało i krew nie mogą posiąść królestwa Bożego, i że to, co zniszczalne, nie może mieć dziedzictwa w tym, co niezniszczalne” (1 Kor 15,50). Należy jednak pamiętać, że święty Paweł absolutnie nie miał „na myśli kwestii nierozkładalności świętych relikwii, a mówił o tym, że w życiu przyszłym [...] ciała ludzkie będą zupełnie inne od obecnych, ulegających zniszczeniu”. Por. tamże, s. $70-71$. 
strzeganie śmierci i rozumienie ceremonii czy też praktyk związanych ze szczątkami osób, które zostały uznane za święte, na przykład z racji ich głębokiej wiary w czasie ziemskiego życia, poniesionej śmierci męczeńskiej z tego powodu, czynionych przez nich cudów albo miłosiernych czynów, które pełnili. To właśnie chrześcijaństwo doszło do wniosku, że patrząc na ciała bądź kości tych osób albo na rzeczy z nimi związane, jednocześnie powinniśmy przypominać sobie ich ziemską walkę lub zmagania, przez które osiągnęli doskonałość życia chrześcijańskiego.

Kult relikwii nie może ograniczyć się do zewnętrznych gestów, które wtedy byłyby puste, niezrozumiałe, a z czasem zyskałyby miano magicznych. To nie jest kult dla samego kultu. Rozmyślając nad życiem świętych, jesteśmy zaproszeni, aby czerpać z nich wzór i również podążać drogą do świętości, tak jak oni. Tak rozumiany kult relikwii, a właściwie kult świętych, z relikwiami których możemy obcować i obdarzać je szacunkiem, mobilizuje nas do prowadzenia takiego życia, abyśmy kiedyś mogli również dostąpić zbawienia. Tego rodzaju kult kieruje nasze myśli w stronę Jezusa Chrystusa, byśmy po śmierci mogli wpaść w Jego ramiona. Reasumując, można stwierdzić, że na szczęście chrześcijański kult świętych i ich relikwii przetrwał przez prawie dwa tysiące lat i jest wciąż żywy. Bowiem dopóki mamy tego rodzaju kult, niezwykle inspirujący i pobudzający nas do działania, dopóty będziemy mieli okazję odkrywania dzięki niemu własnych dróg prowadzących do świętości, której w dzisiejszych czasach tak bardzo brakuje.

Streszczenie. W poszukiwaniu genezy, rozwoju oraz sensu chrześcijańskiego kultu świętych i ich relikwii. Studium historyczno-teologiczne. Autor tego artykułu przedstawił bogatą historię kultu relikwii od czasów pogańskich do czasów współczesnych, a także zwrócił uwagę, że chrześcijański kult świętych i ich relikwii pojawił się dopiero po śmierci dwunastu Apostołów. I jest on wciąż aktualny oraz sensowny.

Słowa kluczowe: kult; święci; relikwie; relikwiarze.

Abstract. The Search for Genesis, Development and Meaning of the Christian Cult of Saints and Their Relics. Historical and Theological Study. The author of this article outlined the rich history of the cult of relics from pagan times to the present day and he drew attention that the Christian cult of saints and their relics appeared only after the death of the twelve Apostles. And it is still valid and meaningful.

Key words: cult; saints; relics; reliquaries. 


\section{BIBLIOGRAFIA}

Bouchard F., Wielkie cuda pobożności czyli skarby Kościoła wsparciem dla Ludu Bożego, tłum. C. Bogdali, Gdańsk 2002.

Budziarek M., Kult relikwii w starożytnym chrześcijaństwie, „Ruch Biblijny i Liturgiczny” 5 (1979), s. 276-280.

Charkiewicz J., Relikwie świętych w prawosławiu, Warszawa 2010.

Feliś K., Pierwsze ślady kultu Relikwii, „Ateneum Kapłańskie” 1 (1909) 5, s. 419-437.

Kodeks Prawa Kanonicznego. Przekład polski zatwierdzony przez Konferencje Episkopatu, red. K. Dynarski, Poznań 2008.

Komentarz do Kodeksu Prawa Kanonicznego. Tom III/2. Księga IV. Uświęcające zadanie Kościoła. Część I. Sakramenty. Część II. Pozostałe akty kultu Bożego. Część III. Miejsca i czasy święte, red. W. Góralski, E. Górecki, J. Krukowski, J. Krzywda, P. Majer, B. Zubert, Poznań 2011.

Marecki J., Rotter L., Jak czytać wizerunki świętych. Leksykon atrybutów i symboli hagiograficznych, Kraków 2013.

Pismo Święte Starego i Nowego Testamentu. W przekładzie z języków oryginalnych, red. K. Dynarski, wyd. 4, Poznań-Warszawa 1984.

Przypadki rytualnej nieczystości, w: Pismo Święte Starego i Nowego Testamentu. Najnowszy przekład z języków oryginalnych z komentarzem, red. T. Brzegowy, Częstochowa 2009, s. 298-299.

Sinka T., Kult relikwii Świętych $w$ aspekcie historyczno-liturgicznym, „Ruch Biblijny i Liturgiczny" 3 (2003), s. 193-200.

Śmierć Elizeusza, w: Pismo Święte Starego i Nowego Testamentu. Najnowszy przekład z języków oryginalnych z komentarzem, red. T. Brzegowy, Częstochowa 2009, s. 700.

Szczepkowska-Naliwajek K., Relikwiarze średniowiecznej Europy od IV do początku XVI wieku. Geneza, treść, styl i techniki wykonania, Warszawa 1996. 